This item was submitted to Loughborough's Institutional Repository (https://dspace.lboro.ac.uk/) by the author and is made available under the following Creative Commons Licence conditions.

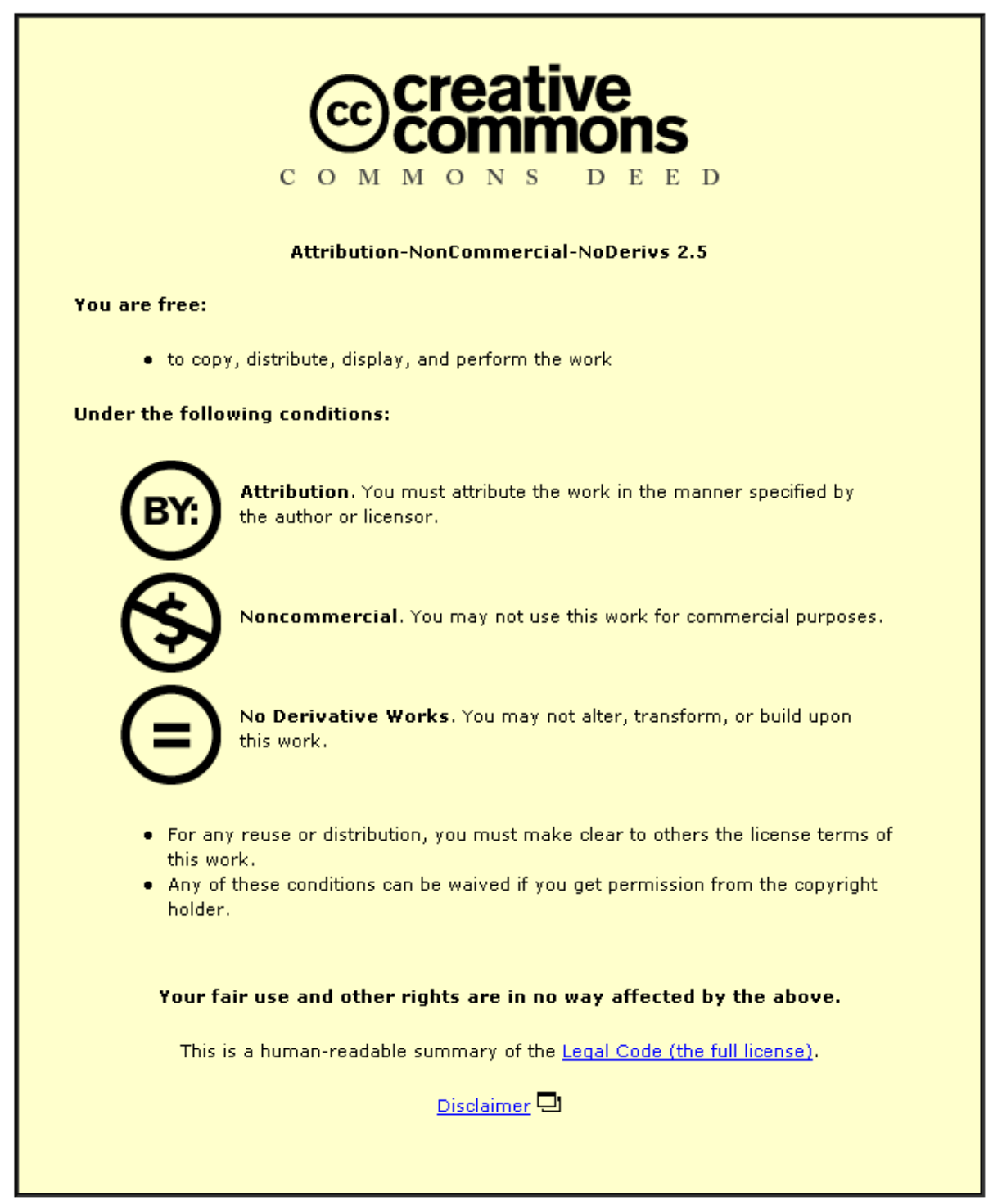

For the full text of this licence, please go to: http://creativecommons.org/licenses/by-nc-nd/2.5/ 
Evans and Cheevers's A Short Relation in Context: Flesh, Spirit, and Authorit...

Catie Gill

The Huntington Library Quarterly; 2009; 72, 2; ProQuest Direct Complete pg. 257

\title{
Evans and Cheevers's $A$ Short Relation in Context: Flesh, Spirit, and Authority in Quaker Prison Writings, 1650-1662
}

\author{
Catie Gill
}

\begin{abstract}
This is a Short Relation of Some of the Cruel Sufferings... in the Inquisition in the Island of Malta (1662) was written from a Maltese prison where its authors, the English Quakers Katherine Evans and Sarah Cheevers, were being held by a branch of the Roman Inquisition. In this article Catie Gill examines the features of $A$ Short Relation that are related to earlier Quaker accounts of imprisonment-the subjects' forthright resolve in denying their imprisoners' authority, their foregrounding of bodily suffering, and their evocation of Quaker antinomian and martyrological traditions. The article focuses particularly on the way the gender of the authors affected their experience and their account of it. Keywords: persecution of Quakers, martyrology, women and religious authority, mysticism and prophecy, Roman Inquisition
\end{abstract}

WHEN TWO QUAKER WOMEN EN ROUTE to Alexandria docked at Malta in December 1658, they were imprisoned by the Roman Inquisition, first under house arrest, and then in the jail, having come to its attention after they preached on the island and distributed Quaker pamphlets. The women had been intending to visit the Holy Land; instead they served more than three years in a Maltese jail. During their incarceration, they were visited by co-religionist Daniel Baker, who brought their prison narrative, $A$ Short Relation, to the press after his return to England. ${ }^{1}$ The Catholics-Franciscan friars and officers of the Inquisition-were seeking to convert the women, which was in line with the Inquisition's belief that it performed a "salvic" function by reorienting unbelievers to the true faith. A much-tempered institution by the 1650 , in view of the fatal interventions of the previous century, the Holy Office of

1. Katharine Evans and Sarah Cheevers, This is a Short Relation of Some of the Cruel Sufferings... of Katharine Evans and Sarah Che[e]vers, in the Inquisition in the Isle of Malta (London, 1662), 77. The text also contains an account of Baker's travels in Europe and Asia. All further page references are given in the text.

Pp. 257-272. 02009 by Henry E. Huntington Library and Art Gallery. ISSN 0018-7895 | E-ISSN 1544-399x. All rights reserved. For permission to photocopy or reproduce article content, consult the University of California Press Rights and Permissions website, http://www.ucpressjournals.com/reprintInfo.asp. DOI: 10.1525/hlq.2009.72.2.257.

HUNTINGTON LIBRARY QUARTERLY | VOL. 72, NO. 2 
the Inquisition nevertheless had the authority to imprison, interrogate, and torture captives, and its secular arm could impose a sentence of death. ${ }^{2}$ Andrew $P$. Vella's study of the case, based on notes in the inquisitorial archives, indicates that decisions about Evans and Cheevers's case were made in Rome, by Cardinal Barberino, beginning with his order to keep them under house arrest pending a review of their activities. In February 1659, Barberino instructed the Maltese inquisitor to move the women to the prison; finally, in August 1663, Rome sent the reprieve, releasing them from prison but placing them under the charge of the English consul until passage to England could be arranged. 3

Despite the length of the sentence, which could have broken their spirit, the texts the women wrote from prison show that they remained undaunted, even defiant: they were unwilling to concede any matters of Catholic faith and maintained that the Inquisition abused its power. As we examine the themes of these prison writings, the accounts of disputes over the authority vested in the two sides, Catholic and Quaker, become central, since these show how power was exercised. The women represented themselves as prophets and martyrs, hence positioning their story within a radical biblical tradition. The friars, meanwhile, maintained that to leave these women's views uncontested was to damn them: "a thousand Devils" will condemn them to hell, one of them observed (77). In the course of the disputes that are recorded in the Quaker-authored pamphlet accounts, women are ranged against men, a minority sect against the hegemonic power of the Catholic Church, and the English against the Continental "other."

These differences are often figured by the Quakers as the natural antagonism between flesh and spirit. In doing so, as we will see in the course of this article, Evans and Cheevers figured their responses to the Roman Inquisition through paradigms that can be traced within the wider corpus of Quaker texts from the first decade of the movement's existence. According to John Knott, "no religious community of the late seventeenth century suffered more than the Quakers or did more to record and publicise their sufferings." 4 Evans and Cheevers's text should be seen as a resonant, personal response to the circumstances of imprisonment (or persecution, as they would have seen it); at the same time, their writing is part of a larger argument that was being mobilized in the hundreds of Quaker documents relating to the trial, incarceration, punishment, and sometimes death of those Quakers who had experienced what Isaac Pennington, in Concerning Persecution (1661), termed the "opposition of the flesh against the spirit."5 The demonstrable breadth of Quaker suffering, in terms of the

2. E. William Monter and John Tedeschi, "Towards a Statistical Profile of the Italian Inquisitions, Sixteenth to Eighteenth Centuries," in The Inquisition in Early Modern Europe: Studies on Sources and Methods, ed. Gustav Henningsen and John Tedeschi (DeKalb, Ill., 1986), 130-57.

3. Andrew P. Vella, The Tribunal of the Inquisition in Malta (Malta, 1964), 31-37.

4. John R. Knott, Discourses of Martyrdom in English Literature, 1563-1694 (Cambridge, 1993), 216.

5. Reprinted in Early Quaker Writing, 1650-1700, ed. Hugh Barbour and Arthur O. Roberts (Grand Rapids, Mich., 1973), 374. 
number of recorded cases of imprisonment, is indeed notable, estimated at two thousand cases in the 1650 . $^{6}$ But for the purposes of this article, what matters most is not these empirical matters, but the community's rhetorical and figurative responses to such opposition. Specifically, I will be examining how Quaker writers disputed the judgments of courts or of inquisitors that deemed them religious criminals.

I have argued elsewhere that Quaker women's speech patterns are of particular importance in understanding the textual representation of their suffering.7 To summarize briefly here, Quakers resist censure by speaking out against injustice, as they see it. Their writing is, in a sense, an extension of their public testimony reconfigured for a readership, bringing their voices to the wider public through the processes involved in writing and publication. Their voices, however, often bear a trace of the original moment of censure, meaning that silence is not the opposite of speech but the productive moment at which protest begins. We will see that Evans and Cheevers's writing provides some examples of this dialectic, but for our purposes the clearest precedent in early Quakerism occurred when the Quaker Dorothy Waugh was placed in a scold's bridle as punishment for her public speaking. Out of this censorious punishment, a Quaker woman's voice emerged. Though she had been branded a scold and bridled, Waugh wrote to upbraid the law's officers for their "ungodly practices," seeking to expose the severity of the punishment. The fact that she was silenced "with the stone weight of iron upon my head to keep me from speaking," created the need to protest afterward, in print, that there were no laws that could back up the "charge." 8 The voice these women claim when writing about punishment, then, is often directly or indirectly a response to others' ineffective attempts to silence them. But rather than reading such texts as straightforward repudiation, which might imply a clear victory over all opposition to women's public speaking, I see their writings as figuring the complex anxieties that attended women's vocality. In the course of this article, therefore, I will be examining the anxieties that surround women's public expression of faith, aiming to explore the question of these women's identities as writers and as sufferers.

Though I will also be tracing some points of similarity between Evans and Cheevers's writing and the wider corpus of Quaker suffering, it is important to point out that they wrote not only (like Waugh) as women Quakers galvanized by the injustice of their persecutors but also as English Christian dissenters opposed to Continental Catholics. This produces a further imperative to the writing: to resist the devaluation of their faith by presenting Catholicism as alien, foreign, and corrupt. Other Quaker writings to which I will refer belong to a different historical context, treating experiences in England. However, as Catherine Gray has rightly observed, Evans and Cheevers's $A$ Short Relation speaks to a dual audience: it "opposes Anglicanism at

6. William Braithwaite, The Beginnings of Quakerism, 2nd ed. (York, U.K., 1981), 451.

7. Catie Gill, Women in the Seventeenth-Century Quaker Community (Aldershot, U.K., 2005).

8. In James Parnell, The Lambs Defence (London, 1656), 29-30. 
home and Catholicism abroad."9 Baker, the compiler of the text, placed this construction on the women's experiences, showing that he was thinking not only of the Catholic context but also of Quaker persecution among the English. In the "Epistle to the Reader," Baker explains the cause of Quaker mass imprisonment in England as the "exalted" worldliness of rulers who have been "quenching" religious worship (sig. A4r). In this construction, the Catholics are both "other" and "not-other," since Anglican churchmen are, in a sense, guilty of silencing Quaker testimony in ways that are often represented as not so dissimilar from the methods of the Catholic Church. The narrative impulse, then, of Evans and Cheevers's text was both a direct response to their specific circumstances and a pointed foregrounding of wider questions of faith in Cromwellian England.

\section{Quaker Protest, from Voice to Text}

The material facts of Evans and Cheevers's success in writing their experiences in A Short Relation are worthy of note, and they also confirm the value that the wider Quaker community placed on published testimonies of persecution. The women in the Maltese jail were "deprived of Ink and Paper for the great part of their confinement," observed George Robinson when republishing a compilation of their pamphlets for eighteenth-century readers. ${ }^{10}$ The fact that imprisoned Quakers were often deprived of writing instruments is much commented on in their pamphlets about persecution, reflecting the high value they placed on publishing accounts of their sufferings. For instance, Edward Burrough's A Declaration of the Present Sufferings (1659), a summary of a decade of persecution, lists among the catalogue of "injuries and false imprisonments" the fact that, while in prison, "Friends" were "denyed needful sustenance for several dayes together, not suffered to have Pen, Ink, nor paper." 11 The serendipitous juxtaposition of being starved with being deprived of voice, and the punning on the word suffer, seem to make withholding pen and ink as material a deprivation as withholding food. The Friends' high valuation of the literature of persecution is also evident elsewhere. It is neatly summarized by Priscilla Cotton, who explains that "as I was in the prison house, the 11th day of the 6th month, 1656, at evening, the word of the Lord came unto me, saying, take up a Lamentation over England ... publish it, that all may see it."12 For Quakers, the restrictions placed on their writing could register as an attempt by their enemies to silence the voice of their God. These factors help explain why Evans and Cheevers sought so tenaciously to hide their writings from the

9. Women Writers and the Public Debate (New York, 2007), 189. Other texts were Katharine Evans and Sarah Cheevers, A True Account of the Great Tryals (London, 1663); Sarah Cheevers, To All People Upon the Face of the Earth (London, 1663); and Katharine Evans, A Brief Discovery of God's Eternal Truth (London, 1663).

10. A Brief History of the Voyage of Katharine Evans and Sarah Cheevers, to the Island of Malta (London, 1715), iv.

11. A Declaration of the Present Sufferings of Above 140 Persons of the People of God (Who Are Now in Prison), Called Quakers (London, 1659), 24.

12. As I Was in the Prison House (n.p., [1656]), broadsheet. 
inquisitors. The women devised a "private" way of writing to each other, the nature of which is not revealed in the text, probably in order to protect their process and their accomplices. Thereafter, Baker smuggled their text out of the prison, though, he explains, this put his life in "jeopardy" $(21,88) .{ }^{13}$ But these methods were not fail-safe. The Inquisition interrogated the women in an effort to get them to name their accomplices, and Baker was forced to hand over some copies of the writings to the inquisitors $(21-22,49)$. The act of writing, then, was a form of protest against the conditions in prison, and it furthermore reveals the Quaker practice of using sufferings to construct a published image of their community.

When the inquisitors found Evans's writing, they threatened her with being "tyed with Chains," and this depiction of the captors' methods resonates as an image of the constraints in other prisons (21-22). The physical restraint of the body through chaining reminds us that authorities in the early modern penal system sometimes sought to compound the loss of liberty with visceral torment. In a sense, what prison is supposed to accomplish is the dissolution of the subject's identity, which the chaining registers in a material form. Later in the text, one of the women (it is not possible to identify which) explains that a friar threatened to "lay me in Chains, where I should neither see Sun nor Moon" (42). The representation of the prison hence rests on the removal of the sufferer not only from civil society but also, here, from nature in its most essential form, through the deprivation of light. Within this context, it is clear that writing is not only a form of protest but also a way of protecting the self against the deprivations that imprisonment can work on the subject.

The prison writing of Quakers, including that of Evans and Cheevers, is not an impartial assessment of the legal processes, yet their texts often seek to convey verisimilitude, not only by detailing the judgments of their enemies, but also by compiling evidence, such as the charges against them, known as the mittimus, and including it in the text. Quakers did perceive that their suffering gave them a platform from which to critique the legal system. We will see that this brings the voice of the Quaker sufferer to prominence, so for the purposes of my argument the convention of the narrative of suffering will be given greatest emphasis.

Magistrates in England had been instructed by the Council of State to "consider the most convenient way to prevent and suppress all tumultuous meetings of persons, on pretence of Quakers."14 The language clearly points to the criminalization of Quaker worship and to the perception of Quakers as disorderly insurgents. Quakers in England were convicted of a range of offenses-preaching in public, not paying tithes, crimes such as blasphemy. They also caused further offense by refusing to respect social superiors, rejecting codes of common courtesy.

13. For a fuller account of their methods, see my "'Bad Catholics': Anti-Popery in This is a Short Relation (Katharine Evans and Sarah Cheevers)," in Women's Writing Revisited, ed. Paul Salzman, (Aldershot, U.K., forthcoming).

14. Norman Penney, Extracts from the State Papers Relating to Friends (London, 1937), 1. 
The principle behind much Quaker belief and behavior was resolutely antinomian. Obedient to God alone, not legal processes that they saw as suppressing their testimony, Quakers spoke of themselves as victims of oppression. Burrough, for instance, reflected that "when I considered the long suffering, the patience, the forbearance of the Lords people, under all their sufferings ... and when I looked at their innocency... my heart was made glad ... the unjustness of their suffering did more appear." 15 The authors of The Saints Testimony Finishing through Sufferings (1655), writing in less martyrological terms, bluntly affirm that the evidence they provide will teach lawmakers "how to act" more justly in future. ${ }^{16}$ Quakers, then, sought to dispute the very terms in which their imprisonment was justified. One of the conventional features of Quaker prison writings is the signaling of the apparent illegality of the ruling in the courtrooms, which we will later see in the account by Evans and Cheevers.

Trial scenes provide particularly pointed and dramatic examples of antinomian belief. Often, texts exult in the defendant's quick-thinking wit in the courtroom, with the trial becoming a showpiece for the believer's opinions. The Leveller John Lilburne is perhaps one of the best-known figures in mid-seventeenth-century literature in this respect, for his performances (I use the word advisedly) could turn a jury against those bringing the charges. But Quaker leader George Fox also cut a figure, in his own way. When tried in 1664, for instance, his anarchic designs came through when he refused to accept even the most basic premise of a trial: that the defendant should swear on the Bible. The report comments on his words and his actions:

GF. Give me the book in my hand, which set them all a gazing, and as in a hope he would have sworn; then when he got the book in his hand, he held up the book and said, this book commands me not to swear if it be a Bible I will prove it; and he saw it was a Bible, and he held it up, and they pluckt it forth of his hand again, and cryed will you swear, will you take the Oath of Allegiance yea or nay. ${ }^{17}$

The witness of this scene, another Quaker, appears to be taken by Fox's visual gestures as well as this combative exchange (the "[he] said"/ "[they] cryed" suggests a verbal sparring match). The observer's effort and ability to record the scene is evident in the use of almost mimetic language in the relation of Fox's colloquial speech, which gives him presence and immediacy while also subtextually suggesting that the court's irritation with him could result in a guilty sentence (which, in the Quakers' eyes, would of course be unjust). Recorded accounts by witnesses use authenticating features such as realistic dialogue in order to prompt their readers to see Quakers as falsely accused. Friends kept detailed accounts, and trials were often presented as an opportunity for defendants to speak at length on religious matters, in order to show how far they

15. Declaration of the Present Sufferings, 38.

16. The Saints Testimony Finishing through Sufferings: or, The proceedings of the court against the servants of Jesus (London, 1655), 7.

17. Margaret Fell, The Examination and Tryall of Margaret Fell and George Fox (London, 1664), 8. 
would take the principle of liberty of conscience. To that extent, attempts to suppress Quakerism through the legal process could backfire completely: instead of silencing them, the authorities provoked them to be even more publicly antagonistic to the law.

Women's speaking in court presents not only the antinomian rejection of the law that we have seen in Fox's defense but a further spectacle: the intransigence of a woman in the public sphere. The authorities brought many cases against Quaker women-perhaps because their greater prominence in the public sphere inspired a more urgent defense of what we would now term patriarchal order. The Quaker Sarah Tims, for example, was told that "washing the dishes" should be "the first point of law" to her. ${ }^{18}$ Such an example is hardly unexpected, but once again, silencing produced the circumstances in which women's public testimony needed to be defended. ${ }^{19}$ When Hester Biddle was examined, the textual account of her trial figured a subtextual response to her testimony. On the one hand, the response of the courtroom is reported as literal surprise: "What a woman speak! The Jury and some of the Bench said, they never heard of a woman to speak before." ${ }^{\circ}$ On the other hand, the comment of the court seems laughably extreme, the expression inept, as though the indignation expressed is really that of the Quaker writer of this account, who cannot comprehend that women would silently accept the judgment of a court. There are also examples of women who demanded the right to defend themselves in court, as was the case with Anne Audland, who claimed that she was wrongly imprisoned, her crime being witnessed to by false accusers, and she having "not the liberty to answer for my self." 21 Audland wrote a lengthy denunciation as a result of this perceived injustice, and it was published alongside an account of her trial. ${ }^{22}$ The condition of imprisonment created the reason to write.

These examples of the way published texts figured Quaker antinomianism suggest the paradigms that could be cross-culturally applied to the experience of persecution in Malta. Evans and Cheevers's imprisonment was represented as unjust by Baker, who had experienced hostility when ministering in Europe and Asia-situations he writes about in A Short Relation. Hence, Baker's sympathy for the women was based on identification; he argued that their case had the "sound and savour of pure innocency and truth" (67). Their text, likewise, recognizes the collective efforts to foreground suffering as an act of Quaker fortitude, brought to "publick view" in order that "every Member of the one Body [the Quaker movement] may have a right understanding" (66). Moreover, just as Quakers in England represented themselves being upbraided with what we would now term antifeminist jibes, so too Evans and Cheevers were

18. Saints Testimony, 8.

19. Tims's Saints Testimony contains a defense of women's public speaking.

20. "Here Follows the Tryal of Esther Biddle, and Three Women More," in Anon., A Brief Relation of the Persecutions and Cruelties (n.p., 1662), STC B4629, 35.

21. Saints Testimony, 34.

22. I have argued elsewhere that Audland's voice is stifled in the textual account of her trial, probably written by male Quakers; this suppression is an example of the Quaker movement's own anxiety about women in the public sphere; see Gill, Women in the Seventeenth-Century Quaker Community, 55-56. 
shown reacting to the attitudes that their text ascribes to their inquisitors and the friars. Because Evans and Cheevers refused to recognize the authority of the pope, for instance, they were instructed to "be obedient" (8). Furthermore, the friars threatened Sarah Cheevers with a halter, proposing to use the instrument that most literally expressed patriarchy's will to tame the disobedient by restraining the unruly tongues of scolding women (22). As Rosemary Kegl has argued, when the friars depict the women through the stereotype of the disobedient wife, the Quakers respond with a critique of patriarchy; they are no more answerable to the friars than they would be to a drunken husband. ${ }^{23}$ These debates over the authority of the Catholic Church and its officers, then, register commonplace anxieties that spiritual women's behavior is indistinguishable from the scold's, their preacherly roles expressing nothing more than female desire for preeminence. Such a perspective, of course, was no more common among Catholics than among Protestants; the women engage with the friars in roughly the same way as other Quaker women responded to magistrates in Cromwellian England.

One telling incident stands out as a moment of particular significance in the representation of the two women's imprisonment, adding complexity to the interpretation of what was at stake in $A$ Short Relation. There is no specific depiction of a trial in Evans and Cheevers's text, in part because their imprisonment bears the hallmarks of an extended trial, although entirely within the domain of the prison. A dispute early in their sentence, though, was particularly focused on establishing the Inquisition's "salvic" function, to convert non-believers to the Catholic faith. The women contested the terms by which they were imprisoned, seeing this as an "abuse" of power. The incident I am most interested in, however, also reveals their attitudes about authority with respect to gender. Specifically, the women refuse to bow to the name of Jesus, thereby rejecting one ceremonial feature of Catholicism; but this refusal is also a sign of disorderliness that their writing must counter. The record of both sides of the debate, as in the account of Fox's trial, has an element of theatricality. The woman (it is not possible to identify whether it was Evans or Cheevers) explains:

$\mathrm{He}$ [the friar] askt me, whether I did not think it meet for every one to bow at the Name of Jesus, I said, Yea, He said, Jesus, and bid me fall down, or bow my body. I told him, My heart and whole body was bowed under the Name of Jesus, but I should not stoop to his will, nor any man's else: He that departeth from iniquity, boweth to the Name of Jesus; but those that live in sin and wickedness do not stoop to the Son of God. And he told me, they stood in the same Power the Apostles did, and were guided by the same Spirit as they were. I asked why they did abuse their Power then, and make use of Carnal Weapons. He said, they did not, they were all spiritual, their Inquisition, \& their Chains and Irons, and all is spiritual.

23. Rosemary Kegl, "Women's Preaching, Absolute Property, and the Cruel Sufferings (For the Truths Sake) of Katharine Evans and Sarah Chevers," Women's Studies 24 (1994): 51-83 at 68. 
And he asked, Whether we judged them all damn'd that were not of our Judgment. I said, Nay, we had otherwise learned Christ; those that were in a Reprobate condition to day, the Lord may call them out of it tomorrow, for what I know. He said, They did judge us damn'd, and all that were not of their Faith. I told him, Man's Judgement we did not matter. (32-33)

But whereas Fox was not subject to judgments on his masculinity, the women were implicitly defending themselves from anticipated antifeminism by showing that their subordination to Christ was greater than that of the Catholics. The amplification of the language makes this evident, as the writer emphasizes that not only her heart but also her "whole body" bows to Jesus. This unequivocal submission suggests that the woman recognized this moment as a possible trap. The friar may think he will be able to expose the woman's ungodliness through her insubordination, but he is outsmarted. The woman writer may think that the scene shows the vaingloriousness of men for believing they have the godly authority to imprison the faithful. What is left, particularly in the antinomian final line, is the sense that there is little possibility of squaring these different perspectives on the obedience of women.

There were many unresolved issues in these Quaker women's justification of their right to challenge their inquisitorial captors, which supports the argument that women negotiated entry into public dispute by exploiting tensions-not by achieving full spiritual equality with men. Quaker writers often cite a biblical text that God is "but one in the male and female," and this is a point affirmed by Baker in the text of A Short Relation (84). However, Evans and Cheevers anticipated hostility and, I would argue, many of the Quaker texts in which a woman maintains a vehement tone bear traces of the original restrictions that they were reacting to. For instance, when Hester Biddle asserts, "I will not be quiet ... I will not be silent," there is a sense that she is still defining herself in relation to antifeminist values. ${ }^{24}$ In the next part of this essay, I will move from considering the vocal testimonies of Quaker sufferers to assessing the ways in which their corporeal suffering was represented.

\section{$\sim$ Quaker Suffering, from Body to Word}

The theological context for Quaker sufferings, and therefore the corporeality of this experience, relates to the believers' sense of their connection to the divine. Quaker women prophets represented themselves as vessels and, as Richard Bauman explains, the theological way of signaling this was for them to say that their God not only spoke "within Quakers but through them." 25 Katharine Evans and Sarah Cheevers, in like manner, affirm that their authority to challenge the Catholic inquisitors was divinely sanctioned since "god," they explain, "was not wanting to us at any time, for Power nor words to stop the mouths of gain-sayers of his Truth" (22). The prophet, therefore, is

24. The Trumpet of the Lord (London, 1662), 14.

25. Richard Bauman, Let Your Words be Few: Symbolism of Speaking and Silence among SeventeenthCentury Quakers (1983; reprint ed., London, 1998), 25. 
both the site of God's revelation and a person who can silence the oppressor. Quakers often wrote of the movings or openings of the spirit that worked within them, and particularly in the christopresentist focus of early writings, they wrote of a divinizing light witnessing within them (the inner light). ${ }^{26}$ It has been noted that Quakers, unlike other sectarians of the period (for instance, Baptists), very rarely expressed doubt after making their confession of faith. ${ }^{27}$ The Quaker prophet, speaking and writing for her God, and representing herself as saved, would bear persecution as though it were the condition of the godly to oppose the unrighteousness of their society as they saw it. In To the Priests, for instance, two Quaker women prisoners say that their accusers were of "the same generation of Cain ... that persecuted the Apostles and put them to death." ${ }^{28}$ The perception that Quakers' fortitude echoed that of the first martyrs of the Christian church makes their sufferings an affront to the impious.

The account of Dorothy White's preaching in a church in Waymouth will serve to exemplify the intersection between the prophetic and the martyrological currents of thought in early Quakerism. It is a fairly typical account that will begin to contextualize Evans and Cheevers's responses to the Italian Inquisition and further develop the link between the voice and the body. White's preaching led to her writing an account both of the spirit that had moved her to it and of the congregation's opposition to her. The passage I will quote shows once again how effectively Quaker writings could represent the terms in which others objected to the prophet, even as the text refuses such definitions. White explains:

The Lord ... several times moved me to go into your steeple house, in the time of your worship, fore-seeing the great misery and desolation that is coming upon you, shewen me by the Lord; But before I could deliver what the Lord sent me to deliver, they set hands on me, and put me forth, and carried me to the prison, and told me that would put me in, but did not; It did not lie in their power to do it; but when I came up again, the Lord led me in again, and many strived against me, and put me out again before I had done delivering the message of the Lord; Again, the word of the Lord came unto me, Go and say the Lord of hosts hath sent thee to bear witness against the Idol Shepherds; But many strived against me; Go cry against the foolish Prophets that Preacheth lies in my name; by the power of the Lord I was brought thither, to fulfil his will, and to deliver his word faithfully, which word is like a fire and like a hammer, that breaketh the rocks in pieces that cannot be stayed: But two feirce [sic] spirited men stirred up with much wrath, came and haled me forth, and said it was the Devils work, and that I looked like the Devil ... [but] I was sent of God. ${ }^{29}$

26. Christopresentism is the term commonly used to describe the Quakers' belief that they had an inward connection to Christ.

27. Owen Watkins, The Puritan Experience (London, 1972), 178.

28. Priscilla Cotton and Mary Cole, To the Priests (London, 1655), 2.

29. A Diligent Search (n.p., [1659]), 7. 
The insistence of White's God that she convey his word (an anticlerical message pieced together from various biblical texts) is evidenced in the prophet's own bodily reaction to God's word: it is experienced as the burning of a fire and the beating of a hammer within. To White, God's word has a corporeal reality; Quaker writings, indeed, often figured the merging of the believer with her God. This sense of the divinizing presence is precisely what enables White to refuse the unholy label that her opponents gave to her. What is significant about White's writing and, as we shall see, that of the Quakers imprisoned in Malta, is that the connection between diabolism and prophecy in the minds of others is made apparent.

Like several of the most renowned Continental female mystics, and like coreligionist Dorothy White, Evans and Cheevers aspired to spiritual authority. Evans explains in conspicuously sensory terms, for instance, that she has "written the things which I did hear, see, tasted and handled of the good Word of God" (12). ${ }^{30}$ To the dominant Catholic culture, visionary mystics could seem to be problematically autonomous loose cannons, so the Church rarely sponsored mystical women; more often, the Inquisition was alerted to their behavior as suspicious. ${ }^{31}$ By that measure, prophetic audacity becomes an unstable position to argue from, especially given that the Inquisition would routinely employ demonologists and physicians, in addition to its theologically trained inquisitors, to assess the condition, spiritual and bodily, of those it restrained. ${ }^{32}$ Indeed, the official ruling on Evans and Cheevers was that they were mad, a position implying their diminished responsibility. 33 Women were also believed to be more susceptible to the devil, owing to their weakness, and according to the text of $A$ Short Relation, this was a view held by the Catholic friars: Sarah Cheevers was told that she was led by an "evil spirit," and that many like her were "burnt" as witches (73). The women, by contrast, had no institutional authority to back up their judgments, except the doctrines of the Quaker faith; but by positioning themselves as prophets, they could proclaim the judgment, as they saw it, of their God.

Evans and Cheevers's account of their imprisonment shows that they embraced the roles of prophet and of sufferer despite, or perhaps because of, the suspicion they

30. Evans here alludes to Hebrews 6:5; I infer it is Evans because Cheevers is referred to by name earlier (on page 11).

31. For European female mystics, see, especially, Alison Weber, Teresa of Avila and the Rhetoric of Femininity (Princeton, N.J., 1990); Stacey Schlau, "Following St. Teresa: Early Modern Women and Religious Authority," MLN 112 (2002): 286-309; and Caroline Walker Bynum, Holy Feast and Holy Fast: The Religious Significance of Food to Medieval Women (Berkeley, Calif., 1987). For the Inquisition's treatment of women, see Anne Jacobson Schutte, Aspiring Saints: Pretense of Holiness, Inquisition, and Gender in the Republic of Venice, 1618-1750 (Baltimore, 2001); Geraldine McKendrick and Angus MacKay, "Visionaries and Affective Spirituality during the First Half of the Sixteenth Century," in Cultural Encounters: The Impact of the Inquisition in Spain and the New World, ed. Mary Elizabeth Perry and Anne J. Cruz (Berkeley, Calif., 1991), 93-104; and Joan Curbet Soler, "Privileges of the Soul, Pains of the Body: Teresa de Jesus, the Mystic Beatas and the Spanish Inquisition after Trent," in Gender, Power, and Privilege in Early Modern Europe, ed. Jessica Munns and Penny Richards (London, 2003), 123-39.

32. Andrew Keitt, "The Miraculous Body of Evidence: Visionary Experience, Medical Discourse, and the Inquisition in Seventeenth-Century Spain," Sixteenth Century Journal 36 (2005): 77-96.

33. Vella, Tribunal of the Inquisition, 34. 
provoked when they employed these religious models as an explanation of their experiences. The women insist that "the worst" their Catholic captors could do to them was "but to kill the body," explaining they would "gladly" give their lives nevertheless $(17,37)$. Because they did not know, at the time of writing A Short Relation, whether they would be freed, or whether the Catholic threats of executing them would be fulfilled, their expressions of faith, their martyrological topoi-often repeated in Quaker writing but rarely in such extreme circumstances-stand out. Quakers in England could assert, as did one woman, that they took their "lives in [their] hands" when publicly expressing their beliefs, because some did lose their lives; 34 but in England, the last time a person had been executed for heresy was in 1612.35 Evans and Cheevers's circumstances, however, brought a greater likelihood of martyrdom than almost any other Quaker case of the period. ${ }^{36}$ Consciously drawing on the established tropes for the martyr, therefore, Evans and Cheevers show that their bodies have been weakened, but not their wills. Near death on numerous occasions-because of illness, the squalid conditions in which they were held, or hunger (the women fasted repeatedly during their incarceration) - they pointed to the significance of their weakened bodies. When the friars say the Quakers "must never come forth" from the tiny room to which they were confined, the women aver, "if we had died, we had died as innocent as ever did servants of the Lord" (11). Evans, echoing Luke's description of Christ's suffering (Luke 22:44), says her "sweat was as drops of blood" (9).37 The depiction of the prophet as sufferer is clearly significant, and corporeality pervades the text. Their weakness implies that they manifest greater fortitude in suffering, though they are of the weaker sex, and seeks to show the extent of their pious worship.

The association of femininity with weakness could further register here in ways that show its providential value in this archetypal struggle between the new Protestantism and the Roman Catholic Church. In his address to the readers of $A$ Short Relation, Baker wonders why it should be "accounted such a foolish thing in the eyes of the wise men of this world, to see the wisdom of God disputed through a weak Vessel ... a weaker vessel than the man? (sig. A3r). His comment, suggesting that the women's resolve was a result of their weakness, not despite it, is echoed by Evans and Cheevers. God, they maintained, "kept us in our weakest condition, bold for his Truth" (22). Femininity is being figured in the text explicitly here, not only because it functions as a correlate of weakness, but also because it shows that God can particularly be seen working through them: "[we] were very weak, because the power did work strongly," they explain (77). By the time that George Robinson was writing his eighteenth-century overview of the case, long after the release of Evans and Cheevers,

34. Rebecca Travers, For Those That Meet to Worship (London, 1659), 2-4.

35. See Martyrs and Martyrdom in England, c. 1400-1700, ed. Thomas S. Freeman (Woodbridge,

U.K., 2007), 33. Edward Burrough's Declaration of the Present Sufferings states that twenty-one

Quakers died in prison in the 1650 (title page).

36. Other cases with the potential for martyrdom included those of James Nayler, the New England Martyrs, and the other Quakers imprisoned by the Inquisition. All are referred to in Braithwaite,

Beginnings of Quakerism.

37. My thanks to Thomas Freeman for noting this allusion. 
God's design could be interpreted more succinctly: "the world" persecutes the godly who are "not of this world," so the women would have perished but for their God's intervention..$^{88}$ The terms in which the women's imprisonment was described, then, registered the gendered norms of seventeenth-century society, but not in a fixed or stereotypical way, since we might say that Evans and Cheevers's account collapsed the supposed binary differences between weakness and strength and did so, moreover, for polemical purposes.

The representation of Catholics in the narrative, which is almost unequivocally negative, makes free use of anti-Catholic stereotypes. The apparent weakness of the women implicitly gives greater weight to their depiction of the friars' inhumanity, as the women would have seen it. 39 The pejorative depiction of the friars as "cunning, indefatigable, and industrious opponents," common in Protestant writing, provides a subtext to Evans and Cheevers's account of the friars. $4^{\circ}$ Recording the friars' words so that the reader could judge the men's attitudes leaves little doubt as to what is being suggested by their characterization. The women refer to one of their captors as a "bloody, fiery serpent," for example. In many instances the text gives an immediacy to conversations that, of course, were recorded after the event: "the Father hath almost killed you .. . but I will kill you quite, before I have done" $(20,42)$. It is notable that the dialogue is in the present tense, bringing to life the conversations between prisoner and captor in order, seemingly, to let the speaker's own words condemn him. ${ }^{4}$ What is being figured, here, I believe, is not only the individual's response but also the women's resistance to hegemonic power: the woman's victory is in representing the friar as talking so brutally, voicing his violent fantasy. Moreover, the threat of torture is evidence of the Inquisition's failure; unable to convert the heretic, it sets out to affect all that was left to it: the sufferer's body. This is, therefore, the Catholic religion reconfigured as coercion, as affecting only outer conformity. Catholicism's focus, moreover, is depicted in a way that implicitly establishes the greatest point of contrast between it and the Quaker faith. As we will see, Evans and Cheevers present their relationship to God as inward unity, while other ways of knowing God are derisorily regarded as false. The text, in other words, sets up contrasts between the righteous, inward, and prophetic faith on the one hand, and on the other a servile, self-seeking belief, in which the inward spirit has not been touched: "you have blinded your eyes that you will not see, and stopped your ears ... and hardened your hearts," the women tell the Catholics (43). Evans and Cheevers's prison writings, then, encode the apparent differences between the two faiths for polemical reasons.

38. Robinson, Brief History, 105, 108.

39. They do, however, refer to one "tender hearted" friar (30).

40. This is Frances Dolan's characterization of typical anti-Catholic views in Whores of Babylon (Notre Dame, Ind., 2005), 16.

41. This is the common approach to depicting the friars, though occasionally A Short Relation nudges the reader to the correct interpretation: "the next day they came to sit upon Judgement again [but I say, in the true Judgement they sate not ... a child of Wisdom may understand]" (9; brackets in original). 
The final part of this article will touch briefly on this privileging of inward authority, Evans and Cheevers's way of overcoming the apparent binary division between voice and body through their depiction of the prophetic experience. At issue for Evans and Cheevers is proving their prophetic identity through their inward connection to Christ, experienced as they suffered the breakdown of their bodies through suffering. Evans and Cheevers realize their suffering viscerally, since the conditions in prison "almost killed" them, and they affirm that they were often close to death (42). And within the martyrological context that governed the way religious writers constructed their imprisonment, suffering is an enactment of sacrifice in all its biblical significance. Evans and Cheevers indeed use the word "sacrifice" to evoke what was at stake for them during protracted fasts $(78)$. The language they use to describe the body's pain hence often takes on a biblical register, in order to emphasize that they were becoming one with the religious martyrs, and ultimately with Christ. Near-death experiences were also occasions when their God spoke to them as an inner voice. An example of such prophetic writing occurs after an extended fast, when one woman was greatly weakened:

Then I heard a voice saying ye shall not die. I believed the Lord, and his glory did appear much in our fast, he was very gracious to us, and did refresh us with his living presence continually, and we did behold his beauty to our great joy and comfort, and he was large to us in his promises, so that we were kept quiet and still, (the sting of Death being taken away) our souls, hearts and minds were at peace with the Lord that they could not tell whether we were dead or alive but as they [administered] to us once a day, till the time the Lord had appointed we should eat. (23)

This passage arguably evokes communion, because when the women speak of the "living presence" within them, they seem to imply that they were taking in spiritual nourishment. Their language, in other words, seems Eucharistic even though it does not directly echo Scripture. Where they use direct quotation, they seem purposely to evoke biblical passages that assess the meaning of suffering, and specifically Christ's passion. Like the risen Christ, for whom death had no sting (1 Corinthians 15:65), the women feel that they are entering a higher state where they were neither dead nor fully alive. The body of Christ (his flesh), the words of Paul, and the voice of God have hence been internalized in this biblically resonant passage. The women's physical experiences are defined in biblical terms, as though to break down the distinction between the body and the voice, since the Word speaks through them in their sufferings. ${ }^{42}$

When the body is foregrounded in A Short Relation, then, it is often with the purpose of evoking the Word. Another passage shows how fully this text breaks down the distinction between bodily experience and language through its use of biblical topoi:

42. Theresa Feroli similarly notes that the body/voice/word connection is significant in prophetic writing, specifically in relation to Anna Trapnel; see Political Speaking Justified: Women Prophets and the English Revolution (Newark, N.J., 2006), 97-147. 
The terrors of death were strongly upon me; but three nights after, the Lord said unto me, about the 11th hour, Arise, and put on your Clothes: I said, When wilt thou come Lord? He said, whether at midnight, or the cock-crow, do thou watch. My friend and I arose, and the Lord said, Go stand at the Door. And we stood at the door in the power of the Lord, I did scarce know whether I was in the body or out of the body. (9)

The woman figures her resurrection and prophetic merging with God here through evocative symbolism. God instructs the woman to "arise" as he did Lazarus (John 11:44), who himself prefigured Christ's resurrection. And the moment of bodily disintegration, the loss of ontological boundaries between inside and outside, evokes a passage in 2 Corinthians 12:3 about a prophet whom the apostle Paul praised for his connection to God, "whether in the body I do not know, or whether out of the body." Ellen Macek has observed of female Marian martyrs of the sixteenth century that their figuring of suffering led them to imagine unity with God or Christ. ${ }^{43}$ Likewise, Evans and Cheevers represent the sacred body that knows the meaning of sacrifice through suffering, achieving prophetic identity as the Word speaks through them.

Evans and Cheevers were eventually released from prison, in 1662. The Quakers George Fox and Gilbert Latey had petitioned Ludovic Stuart, the abbot of Haute Fontaine and canon of Notre Dame, successfully obtaining their release, and as Andrew P. Vella has shown, this intervention was timely, since the Inquisition had by then abandoned the possibility of converting the women. 44 Evans and Cheevers's prison writing is virtually paradigmatic: it is fascinating for its depiction of gender and cultural difference, since it ranges man against woman, Catholic against Protestant, and European against English. The text is significant for its indication of how forcefully a woman could defend her faith, despite masculine objections to female agency. A Short Relation nevertheless shows how ambiguous is gender as a component of identity. The women inhabited a feminized mode of religiosity in order to challenge male authority, creating a subject position that was paradoxically both weak and strong in its associations. Their approach, as we have seen, problematically left them open to accusations that they were ungodly. But the women overcame the censure due them as weaker vessels by showing that they had merged with their God through the Word.

In the course of this essay, I have been aiming to explore the connections between Quaker sufferings in England and those in the Maltese jail that held Evans and Cheevers. In examining how the Quaker voice is figured in their texts, I have indicated that their antinomian retorts to their enemies are recorded in order to present a drama of spiritual confrontation-one between the flesh and the spirit, as the Quakers would have described it. This gave women voice, but when they comment about what

43. Ellen Macek, "The Emergence of a Feminine Spirituality in The Book of Martyrs," SixteenthCentury Journal 19 (1988): 63-80 at 70.

44. Tribunal of the Inquisition, 31-37. See also Stefano Villiani's essay in the Oxford Dictionary of National Biography on Katharine Evans. 
led them to write, they often focus the initial moment of censure that had tried to constrain or silence them.

In the course of this essay, it has also become clear that the dialectical opposition between the voice and the body breaks down when the Quakers borrow rhetorical figures of suffering from the Bible and apply these to their experiences. What they are doing, then, is applying a martyrological framework to their writings, which brought with it an implication that ontological categories of self and other, believer and God, were being collapsed as the Word spoke through them. The martyrological context, as we have seen in the works of Quakers writing of their experiences of prison in England as well as in the writings of Evans and Cheevers from Malta, produced prophetic texts that developed the identification of the Quakers with their God through suffering.

CATIE GILL is a lecturer in early modern writing in the Department of English and Drama at Loughborough University. She has published books and articles about Quaker and sectarian writing, including Women in the Seventeenth-Century Quaker Community (2005). 